\title{
The Impact of Islamic Values Implementation on Organizational Commitments to Human Resources Management Practices at University of Muhammadiyah Malang
}

\section{Nazaruddin Malik, Sri Budi Cantika Yuli, and Sudarti}

Lecturer of Economic and Business Faculty of University of Muhammadiyah Malang, Indonesia

\section{Abstract}

This study aimed to discover the impact of Islamic values implementation on organizational commitment to the practice of Human Resource Management (HRM) at University of Muhammadiyah Malang (UMM). Islamic values are established on the principles of Islamic wisdoms, namely the faith, sharia and morality. Organizational commitment as a practice of employee behavior towards the organization comprises loyalty and achievement of the vision, mission, values and organization goals.

Corresponding Author: Sri Budi Cantika Yuli cantikayuli@gmail.com

Received: 10 February 2019 Accepted: 14 March 2019 Published: 28 March 2019

Publishing services provided by Knowledge E

(c) Nazaruddin Malik et al. This article is distributed under the terms of the Creative Commons Attribution License, which permits unrestricted use and redistribution provided that the original author and source are credited.

Selection and Peer-review under the responsibility of the ICIEBP Conference Committee.
Organizational commitment includes affective commitment, continuance commitment, and normative commitment.

This study employed a qualitative approach and was conducted at University of Muhammadiyah Malang (UMM). The subjects of this study were the employees of UMM. The type of data used were primary and secondary data which were obtained through interviews, observation and documentation. Subsequently, the entire data were analyzed by applying qualitative descriptive technique.

The results revealed that the implementation of Islamic values had an impact on the organizational commitment primarily to the practice of Human Resource Management for employees at UMM. HRM practices include the employee recruitment processes which requires prospective employees to have strong and trustworthy personality (Surah An Nahl verse 78; Al Qashash verse 26; Al Anfaal verse 27), the employee selection process that looking for candidates who meet the essential requirements of honest, strong, and knowledgeable (Surah Al Baqarah verses 249-250; Al Anfaal verse 60 ), employees training and career development (Surah Al Baqarah: 30), performance appraisal (Surah Al Kahf: 87-88), and compensation (Surah Al A'Raaf: 85).

\section{Keywords: Islamic Values, HRM Practice, Organizational Commitment}

\section{Introduction}

Organization as a system of formal, structured and coordinated union of a group that cooperates in achieving certain goals (Hasibuan, 2014) has several elements, i.e. human, cooperation, mutual goals, equipment, environment, natural resources and organizational mental framework / construction. 
The success of an organization in achieving the goals and objectives and the ability of the organization in addressing external and internal challenges, is determined by the ability to manage human resources appropriately. Problems of self-development, fairness, reasonableness, expectations, suitability of work with individual's characteristics, and organizational behavior issues are an important part of human resource management (Siagian, 2014).

Human resource management (HRM) is a planning, organizing, mobilization and supervision of procurement, development, compensation, integration, maintenance and termination of employment with the aim of achieving the objectives of an integrated corporate organization (Umar, 2010).

In the field of education, such as universities, human resources are educators (lecturers) and educational workforces (employees of the administration, librarians, and technicians). The Education Performance is a united system in educational organizations, which consists of a number of components namely input, process, output and outcomes. The input components are categorized into two, namely raw input (students) and instrumental input (curriculum, infrastructure, cost, lecturers and employees). As an instrumental input, the existence of lecturers and employees are very strategic since they are determinant factors to bring students become more meaningful outcomes in society.(Ulfatin \& Triwiyanto, 2016)

In terms of empowering human resources of an organization, the pattern and atmosphere of the work climate in the organization are the main dominant factors. Leadership policy is very influential on improving employee performance. Work activities climate can be created, and it all depend on how superiors and subordinates can create a healthy direct interaction.

Higher Education Institutions as an organization surely requisite employees who are creative, have great performance, productive, and committed to reach and maintain competitive advantage (Malik \& Naeem, 2011). Excellence education can be achieved through universities management that adapt Islamic rules and norms and values in daily work activities. Hence, in order to carry out the institutional management as a mandate, resources are desired to become good role models (uswah hasanah).

It is essential also for an organization to manage their internal environment in order to produce valuable innovations. This will be realized if the organization has conducive cultural values. Culture is a very important factor in improving the effectiveness of the organization. Organizational culture can be an instrument of major competitive advantage, when organizational culture supports organizational strategy and can answer or address environmental challenges quickly and appropriately. Organizational culture is 
closely related to employee empowerment in the organization. Stronger organizational culture will boost greater motivation for employees to move forward together.

As an organization, University of Muhammadiyah Malang (UMM) as Private Islamic University (PTS) under the auspices of Persyarikatan Muhammadiyah, carrying the mandate as the center of learning (learning center) that gave birth to a quality human beings and have Islamic morality expertise. The existence of University of Muhammadiyah Malang (UMM) has the attraction to be investigated more deeply related to the characteristics of Islamic organization culture that has been applied so far. This is in line with one of UMM's mission of organizing professional university institutional governance based on Islamic values.

UMM has proven and is judged to have achieved success in organizing the education process as the largest Muhammadiyah University (PTM), this achievements led UMM to be trustee PTM for Eastern Indonesia. UMM became one of 177 PTM in Indonesia and was recognized by the Organization Leaders as the largest PTM and became the window of Muhammadiyah education.

But in other hand, there are problems in the practice of HRM at UMM (based on the results of interviews), namely:

1. Unfair and not open recruitment system

2. Ineffective decision-making systems, namely the lack of even distribution of duties of university activity committee

3. Unequal employee career development opportunities

4. University regulations are still difficult to be understood by employees

5. Less effective mechanism of policy socialization from University Leaders to Executive Units

This research aimed to discover the impact of Islamic values implementation on organizational commitment to the practice of Human Resource Management (HRM) at University of Muhammadiyah Malang (UMM)

\section{Literature Review}

\subsection{Islamic value}

Essentially, the value of Religion is a value that has the strongest truth base compared to other values. This value comes from the highest truth that comes from God. Human 
mental structure and mystical-transcendental truth are two superior sides that are owned by the value of Religion. Therefore, the highest value that must be achieved is the harmony of all elements of life. Between human will and God's command, between speech and action, or between intention ('itiqad) and deed (Fahmi, Siswanto, Farid, \& Abdurahman, 2013)

Faith (akidah) is a substance that must be believed by the heart, to reassure the soul, and become a belief that does not blend with doubt. The characteristics of Islamic faith are pure, both in the content and the process, which is only God who is obliged to be believed, recognized and worshiped. That belief is not allowed to be transferred to others at all, because it will result in a partnership that affects the motivation of worship which is not entirely based on the call of Allah SWT. This Akidah is manifested in the sentence thoyyibah (Iaa llaaha illallah/ there is no God but Allah). In the process, this belief must be straight, without mediators. Such a faith that will produce an exclusive devotion only to God, free spirited, independence and not submissive to humans and other God's creatures (Fahmi et al., 2013).

Sharia is a way of life that has been determined by Allah SWT, as a guide in living life in the world to lead the hereafter. Sharia means laws and rules that are conveyed by Allah SWT, to be obeyed by His servants. Sharia is also a system of divine norms which regulates human relations with God, human relations with humans, and human relations with other nature (Surah Al Muzammil: 20; Surah Al Ahqaaf: 19; Surah An Nisaa: 58; Surah An Nisaa: 29; Surah An Nahl: 44).

Moral is character, temperament, behavior or character. Morals mean events and are closely related to khaliq which means Creator and meaningful creature created. Morality is a reflection of what is in a person's soul. Good morals are an encouragement of one's faith, because faith must be demonstrated in real everyday behavior. Akhlaq in Islam includes the pattern of relations between humans and God, human beings and humans, and human relations with the surrounding environment (Fahmi et al., 2013)

\subsection{Organizational commitment}

Organizational commitment is the most powerful influence, where people identify requests and are highly motivated to implement them, even when the source of motivation is no longer present (McShane \& Glinow, 2015)

The dimensions of organizational commitment include: 


\subsubsection{Affective commitment}

This commitment refers to the emotional relationship of members to the organization. People want to continue working for the organization because they agree with the goals and values in the organization. People with a high level of affective commitment have a desire to stay in the organization because they support the goals of the organization and are willing to help to realize these goals.

\subsubsection{Continuance commitment}

This commitment refers to the employee's desire to stay in the organization because of a calculation or analysis of profit and loss where the perceived economic value of surviving in an organization is compared to leaving the organization. The longer employees stay with their organizations, the more they are afraid of losing what they have invested in the organization so far.

\subsubsection{Normative commitment}

This commitment refers to the feelings of employees where they are required to remain in their organization because of pressure from others. Employees who have a high level of normative commitment will pay great attention to what others say about them if they leave the organization. They do not want to disappoint their superiors and are worried if their coworkers think badly of them because of the resignation.

\subsection{Human resource management}

Human Resources Management (MSDI) in Islam is all the resources that are used for worship to God, not for others. With the sense of accepting the mandate from God, the ability that is possessed will be enhanced and carried out in order to carry out the mandate carried out. The characteristics that will be reflected in good human resources are Siddiq, Amanah, Fatonah and Tabligh. These four characters are real benchmarks for measuring the excellence of Human Resources.

All these ideal characteristics and circumstances certainly will not be present by themselves but must be with serious effort and extraordinary patience, as His Word in Surah Ar-Ra'd verse 11. 


\subsubsection{Recruitment}

Recruitment is the process of finding prospective employees, which comprises a series of activities that done to decide whether the applicant is accepted or not (Fahmi et al., 2013). Employee recruitment requires two conditions, namely: "tough and trustworthy". Prospective employees have strengths including strong aqidah (quatul aqidah), intelligent (quatul fikr), far-sighted insight (tsaqofah), intelligent conscience (quatul ruhiyah) and professional work (itqon).

\subsubsection{Selection}

Employee selection is a key activity to determine the development of an organization. Leaders must be selective in choosing prospective employees, they ought to be competent, have broad knowledge, sense of responsibility and trustworthiness (amanah/ trust). Being honest, tough, reliable and trustworthy and knowledgeable is an absolute requirement in selecting the appropriate personnel to occupy and carry out a job.

\subsubsection{Employee training and development}

Career development is a condition that indicates an increase in the level or status of someone in their work so can meet needs. The purpose of all career development programs is to adjust the needs and goals of employees with career opportunities available in the organization today and in the future (Widodo, 2015). As stated by (Rivai \& Basri, 2005) that a well-designed career development will assist employees to decide their own career needs, and adjust between the needs of employees and organizational goals.

\subsubsection{Performance assessment}

Performance is the result of the accomplishment of a work both physical and nonphysical (Nawawi, 2008). Performance is the work achieved by a person or group of persons within an organization, in accordance with their respective powers and responsibilities in an effort to achieve the objectives of the organization in a legal, unlawful manner and in accordance with the norms and ethics (Prawirosentono, 2010). Another similar definition suggested by (Irawan, 2000). He define employee performance as the work of an employee which must be shown the evidence concretely and can be 
measured. Performance measurement standards can be performed by measuring job analysis, personal traits, results of work completed, behavior or actions in achieving outcomes(Sudarmanto, 2015).

Meanwhile, (Rivai \& Basri, 2005) claim that performance is a real manners that is presented every person as work performance generated by employees in accordance with its role. (Mas'ud, 2004) states there are five dimensions used to measure the performance of employees individually, among others as follows: 1) Quality. The degree to which the results of the activity are done is almost perfect in the sense of adjusting some ideal way of performing the activity as well as meeting the expected objectives of an activity; 2) Quantity. The amount resulted that is expressed in terms of number of units, number of completed activity cycles; 3) Timeliness. The level of an activity completed at the desired initial time which is viewed from the point of coordination with the output and maximizes the available time for the activities of others; 4) Effectiveness. The level of human resource users in the organization with the intention of raising profits or reducing the losses of each unit in human resource users; 5) Working commitment. The degree to which employees have a working commitment with the company and the responsibility to the company.

\subsubsection{Compensation}

According to (Umar, 2010) compensation is everything that employees receive as remuneration for their work. Compensation according to Islam is associated with the benefits received by someone who works, both the world rewards (financial and non-financial), and the rewards of the afterlife (reward as an afterlife investment). Allah SWT affirmed about this reward in the Surah At Taubah verse 105, An Nahl verse 97 and Al Kahfi verse 30 .

\section{Methodology}

\subsection{Types of research}

This research is qualitative descriptive research that analyze the data collected and further expressed in the form of words and pictures. The words arranged in sentences, for example the result of interview between researcher and informant. The used of qualitative methods is that qualitative approaches are frequently employed to look 
deeper into social phenomena including management studies (Indrawan \& Yaniawati, 2016).

\subsection{Research approach}

This research applies phenomenology approach by examining the experiences that are consciously experienced by the respondent (conscious experience). Phenomenology reveals how humans experience their lives in the world. Qualitative research of phenomenology can be done with three phases of contemplation i.e. apoche (parentheses), phenomenology reduction and dialectical thinking ability (Wirawan, 2012).

\subsection{Data analysis technique}

This research uses 3 (three) techniques of qualitative data analysis, i.e.:

\subsubsection{Data reduction}

Researchers do the steps of summarizing, choosing the essentials issues, focusing on the important objects, looking for themes and patterns, and eliminating unnecessary things. The process of data reduction is done by researchers continuously while doing research to generate core records of data obtained from the results of data extracting.

\subsubsection{Data presentation}

The researchers perform data presentation by providing a set of arranged information that provides possibility of conclusion because the data obtained during the qualitative research process is usually narrative, requiring simplification without reducing the content.

The researchers complete the data presentation to be able to see the whole picture or certain parts of the entire depiction. At this stage, the researchers classify and present the data in accordance with the subject matter that begins with the coding on each sub-topic of the problem. 


\subsubsection{Conclusion withdrawal}

Researchers express the conclusions of the data that has been obtained. In this conclusion step, the researchers look for the meaning of data collected by try to find the relationship, equation, or difference.

Researchers make a conclusion by comparing the suitability of statements from research subjects with the meaning contained with the basic concepts in this study.

\subsection{Conceptual framework}

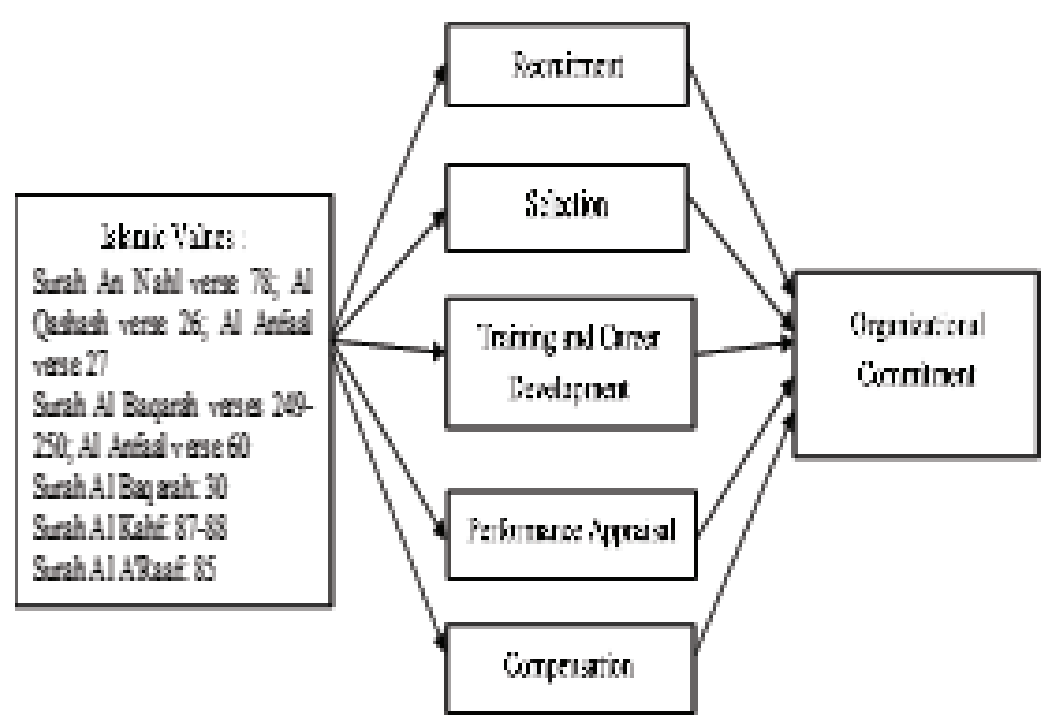

The conceptual framework showed the relationship between Islamic Values and HRM practices and their impact on employees organisational commitment.

Beginning with recruitment, selection and advancing to performance appraisal in UMM, the Islamic values must be embedded in all HRM activities. The Islamic values refer to the execution of basic HRM functions such as recruitment, selection, training and development, performance appraisal, and compensation, which are in accordance with the guidelines of the Qur'an and Hadith

\section{Result and Discussion}




\subsection{Recruitment practice at UMM}

The legal basis and guidelines for the management of the personnel system and the development of human resources at University of Muhammadiyah Malang are arranged by considering the applicable principles including regulations stipulated by the State / The Ministry of Research and Technology - Higher Education (Kemenristek-Dikti) and internally refers to the internal regulations of the Central Executive of Muhammdiyah Organization and the regulations that applied in UMM namely various of Rector Decrees and procedure manuals / employment Standard Operating Procedures.

The executive staff of recruitment is carried out by the team determined by the Rector's Decree which involves the institution as a Human Resources quality assurance unit, namely the Human Resources Development Bureau (BPSDM) with the Bureau of Law and Personnel (BHK) based on the Planning and Development of Education Staff (P2TK-UMM).

This recruitment practice which performed at University of Muhammadiyah Malang is according to the word of God in the Qur'an of Surah An Nahl verse 78; Al Qashash verse 26; Al Anfaal verse 27.

\subsection{Practices of selection at UMM}

The guidelines and legal basis for the implementation of the UMM employee selection system is determined by the Rector Decree related to the selection assessment system, the formation of the Selection team, the microteaching assessment team, the AIK (knowledge of Islam and Muhammadiyah) selection, interviews and Psycho test.

There are 3 (three) categories in the orientation implementation for prospective employees at UMM, based on the employment status hired in the selection, namely: (1). Orientation for prospective foundation permanent lecturers. (2). Orientation for prospective foundation education staffs. (3). Orientation for contracted lecturers and education staffs.

In accordance with the provisions stipulated in article 13 paragraph (3) and (4) of UMM Staffs Regulation, it is explained that employees who are declared accepted as prospective lecturers undergo an orientation period of at least 1 (one) year and the longest of 2 (two) years as prospective or contracted employees.

The practice of selection at University of Muhammadiyah Malang is according to the word of God in the Qur'an Surah Al Baqarah verses 249-250; Al Anfaal verse 60. 


\subsection{Employee training and development practices at UMM}

Each employee at UMM has a right of development in accordance with the provisions contained in the UMM Statute of 2015, Chapter IX article 63 paragraph (1) which states "Main duties, authority of promotion, coaching, career development, and dismissal of lecturers and employees is regulated in accordance with the regulations of Muhammadiyah Organization and the Republic of Indonesia's laws and regulations "as well as the Guidelines for Planning Education Personnel (P2KT).

Employee career development and training is carried out by the university through BPSDM (Human Resource Development Agency). Employee coaching is carried out by conducting ICT training, workshops, further study of S1 and S2 levels, and overall team work building training.

Employee career paths are carried out through workplace mutations every one period (four years) to refresh the atmosphere and career development. In order to improve employee performance, especially for those who hold positions as Head of Affairs (KAUR), periodic activities are held, in the form of Briefing Activities and Workshop of Job Description for Faculty KAUR and Directorate in UMM.

Employee Career Development is carried out in the form of providing opportunities to have self -development through formal and informal education, and employee career development is done through: assignments, advancement and promotions. In an effort to increase work commitment and spiritual development of employees, Quran recitation activities are conducted regularly, as well as routine Islamic studies, grand Islamic studies, commemoration of the Holidays and Directives of the Rector (Rector and Vice Rector). Recitation / Routine Study is carried out by bringing figures from the Muhammadiyah Central Leadership, Muhammadiyah Provincial Leaders, Muhammadiyah Regional Leaders and national figures. Every month of Ramadan, the Syiar Ramadhan is held through activities of Prayer for Ramadhan, Ramadhan Studies, Al Qur'anic Studies, Study of Practical Worship / Halaqah, Tabligh Akbar, and Ramadhan I'tikaf Program (PIR).

The practice of training and career development at University of Muhammadiyah Malang is in accordance with the word of God in the Qur'an Surah Al Baqarah: 30. 


\subsection{Practice of performance assessment at UMM}

The implementation of monitoring and evaluation of education personnel is carried out by the Human Resources Development Agency (BPSDM). For the purpose of evaluating the performance of education personnel, the performance standards of education personnel have been established which are used as guidelines in performance appraisal as well as guidelines for awarding and outstanding education personnel. Assessment aspects of the performance evaluation of education personnel include: performance, organizational loyalty, discipline, team work, leadership, and employee self-development potential.

Monitoring and evaluation activities are carried out periodically and continuously once every 1 (one) year as an effort to improve the Human Resources (HR) management system within the UMM.

Education staff performance monitoring and evaluation procedures cover the following four activities:

1. Brainstorming and drafting evaluation concepts include: a) mapping the aspects that need to be evaluated for performance; b) the drafting of the evaluation which is carried out by the BPSDM manager and special staff.

2. Development of a questionnaire in the employee evaluation system program on the questionnaire development site based on agreed aspects;

3. Data processing.

4. Follow up, Head of BPSDM reports the results of the evaluation to the Vice Rector II and the Head of BHK for decision making as a follow-up in improving HR management.

The performance appraisal practice at University of Muhammadiyah Malang is according to the word of God in the Qur'an, Surah Al Kahf: 87-88.

\subsection{Compensation practices at UMM}

In order to create a conducive work atmosphere to support the quality of employee performance, UMM leaders pay attention to the compensation aspect that can be fulfilled. The real form of compensation is the issuance of various policies in organizational practices that are directed to meet the various needs of employees, as well as 
creating comfortable environment that encourages employees to continue to work in a trustworthy, sustainable and productive manner.

To ensure legal certainty in the implementation of compensation, various Rector Decisions have been issued regarding the implementation of employee compensation, namely:

1. Rector's Decree on adjusting basic employee salaries.

2. Health insurance with employee participation in the BPJS Health (Indonesian Healthcare and Social Security Agency) and Employment Program.

3. Family welfare benefits.

4. Inclusion of employee pension funds.

5. $100 \%$ Hajj financing for education personnel

6. Child education / scholarship allowances, housing facilities and so on.

7. Soft loan assistance from UMM in collaboration with the Banking sector whose implementation is managed by UMM employee cooperatives.

8. Religious Holiday Allowance (THR).

9. Financial aid for accident, disability, childbirth, marriage and severance benefits for temporary workers who resign.

10. The provision of housing facilities, namely the Bestari Indah Housing.

The compensation practice at University of Muhammadiyah Malang is in accordance with the word of God in the Qur'an Surah Al A'Raaf: 85.

\section{Discussion}

Islam as one of the religious is call for the good human behavior and dealing in a matter of Islamic values such as Faith (akidah), Sharia, and Akhlaq (moral). Understanding the human resource practice with implementing of Islamic values help the organization to increase the commitment and plan for long future.

The conceptual framework showed and confirmed a simplified model for the impact of islamic values implementation on organizational commitments to human resources management practices at University of Muhammadiyah Malang. 


\section{Conclusions}

Understanding the Human Resource practice with implementing of Islamic Values at University Muhammadiyah Malang helps University leaders to increase the commitment and plans for long future. The conceptual framework showed and confirmed a simplified model for implementing the Islamic values to strength the human resource practice and the impac of this implementation in the organization commitment.

\section{References}

[1] Fahmi, A., Siswanto, A., Farid, F., \& Abdurahman. (2013). HRD Syariah?: Teori dan Implementasi Manajemen Sumber Daya Manusia Berbasis Syariah. PT. Gramedia Pustaka Utama.

[2] Hasibuan, M. S. P. (2014). Manajemen Sumber Daya Manusia. Jakarta: Bumi Aksara.

[3] Indrawan, R., \& Yaniawati, P. (2016). Metodologi Penelitian Kuantitatif, Kualitatif dan Campuran. (N. F. Atif, Ed.) (2nd ed.). Bandung: Penerbit Refika Aditama.

[4] Irawan, P. (2000). Pengembangan Sumber Daya Manusia (II). Jakarta: Penerbit STIALAN Press.

[5] Malik, M. E., \& Naeem, B. (2011). Impact of Perceived Organizational Justice on Organizational Commitment of Faculty?: Empirical Evidence from Pakistan. Interdisciplinary Journal of Research in Business, 1(1991), 92-98.

[6] Mas'ud, F. (2004). Survai Diagnosis Organisasional, Konsep dan Aplikasi. Semarang: Badan Penerbit Universitas Diponegoro.

[7] McShane, S. L., \& Glinow, M. A. Von. (2015). Organizational Behavior (7th ed.). McGraw Hill Education.

[8] Nawawi, H. (2008). Manajemen Sumber Daya Manusia: Untuk Bisnis yang Kompetitif. Yogyakarta: Gadjah Mada University Press.

[9] Prawirosentono, S. (2010). Manajemen Sumberdaya Manusia: Kebijakan Kinerja Karyawan: Kiat Membangun Organisasi Kompetitif Era Perdagangan Bebas Dunia. Yogyakarta: BPFE Yogyakarta.

[10] Rivai, V., \& Basri, A. F. M. (2005). Performance Appraisal Sistem Yang Tepat Untuk Menilai Kinerja Karyawan Dan Meningkatkan Daya Saing Perusahaan. Jakarta: PT. Raja Grafindo Persada.

[11] Siagian, S. P. (2014). Manajemen Sumber Daya Manusia. Jakarta: Bumi Aksara.

[12] Sudarmanto. (2015). Kinerja dan Pengembangan Kompetensi SDM (3rd ed.). Yogyakarta: Pustaka Pelajar Yogyakarta. 
[13] Ulfatin, N., \& Triwiyanto, T. (2016). Manajemen Sumber Daya Manusia Bidang Pendidikan (1st ed.). Jakarta: PT. RajaGrafindo Persada.

[14] Umar, H. (2010). Desain Penelitian MSDM dan Perilaku Karyawan (1st ed.). Jakarta: PT. RajaGrafindo Persada.

[15] Wirawan, I. B. (2012). Teori-Teori Sosial Dalam Tiga Paradigma (1st ed.). Jakarta: Prenadamedia Group. 